\title{
Present and future of hyperthermic intrathoracic chemotherapy (HITHOC) in thoracic surgical oncology
}

The idea of this special series was born from the fact that the survival in malignant pleural mesothelioma and advanced thoracic tumors is still dismal. Moreover, patients with such invasive tumors are some of the frailest in Society, not only because of the presence of advanced cancer, but also because the consciousness that such advanced cancers, not amenable to surgery, will give them a humble survival.

With this in mind, it is evident that new ideas are necessary to help these unfortunate patients, and this is the main reason why renowned international surgeons from large academic thoracic centers have been invited to share their experience on the role of hyperthermic intrathoracic chemotherapy (HITHOC) in advanced thoracic tumors. I recall that HITHOC is accomplished in the operating room immediately after a thoracotomy or VATS performed for a debulking operation for an advanced chest tumor (1-5). An important step forward in the safety of the procedure has been recently accomplished as it has been demonstrated that an adequate nephroprotection reduces renal complications after HITHOC (6).

This series of $A T M$ makes an important contribution to this subject as patients, surgeons, physicians, oncologists after reading the various articles published in the series will be hugely informed on HITHOC as an adjuvant treatment to cytoreductive surgery of primary and metastatic thoracic cancers such as mesothelioma, M1a-pleural effusion lung cancer, advanced thymomas and metastatic cancers.

In the series I, together with other international colleagues, wrote an article (7) to ask to include HITHOC in the guidelines for malignant pleural mesothelioma (8) as its absence could let some patients and physicians erroneously conclude that the procedure is still investigational despite HITHOC is more than 20 years old $(3,7)$.

In general, all authors of the series agreed for more level of evidence (8) to give HITHOC its place in the decision-making process of advanced malignant chest tumors. It is of particular interest that, confirming previous studies (9-12) HITHOC can prolong the survival in patients with malignant pleural effusion M1a (stage IV) NSCLC. Another strength of this series is that for the first time it has been reported that lung decortication at $42{ }^{\circ} \mathrm{C}$ significantly increased the cisplatin concentration in the lung with a penetration depth of $7.5 \mathrm{~mm}$.

Finally, this series is also dedicated to the new generation of surgeons and physicians who should be able in the future to make precision surgical strategies a reality (13), and consequently treat these highly complex patients individually providing them sophisticated treatments such as debulking surgery and HITHOC with the best management outcomes.

\section{Acknowledgments}

I am in debt of gratefulness to the outstanding contributors for offering their knowledge and practice with HITHOC. Finally, I would like to acknowledge Annals Translational Medicine (ATM) journal for allowing to organize this important special issue, and for the exceptional work done by all the staff.

Funding: None.

\section{Footnote}

Provenance and Peer Review: This article was commissioned by the editorial office, Annals of Translational Medicine for the series "Hyperthermic Intraoperative Chemotherapy (HITHOC) in thoracic surgical oncology". The article did not undergo external peer review.

Conflicts of Interest: The author has completed the ICMJE uniform disclosure form (available at http://dx.doi.org/10.21037/ atm-21-1040). The series "Hyperthermic Intraoperative Chemotherapy (HITHOC) in thoracic surgical oncology" was commissioned by the editorial office without any funding or sponsorship. MM served as the unpaid Guest Editor of the series. The author has no other conflicts of interest to declare. 
Ethical Statement: The author is accountable for all aspects of the work in ensuring that questions related to the accuracy or integrity of any part of the work are appropriately investigated and resolved.

Open Access Statement: This is an Open Access article distributed in accordance with the Creative Commons AttributionNonCommercial-NoDerivs 4.0 International License (CC BY-NC-ND 4.0), which permits the non-commercial replication and distribution of the article with the strict proviso that no changes or edits are made and the original work is properly cited (including links to both the formal publication through the relevant DOI and the license). See: https://creativecommons.org/licenses/by-nc$\mathrm{nd} / 4.0 /$.

\section{References}

1. Sugarbaker DJ, Gill RR, Yeap BY, et al. Hyperthermic intraoperative pleural cisplatin chemotherapy extends interval to recurrence and survival among low-risk patients with malignant pleural mesothelioma undergoing surgical macroscopic complete resection. J Thorac Cardiovasc Surg 2013;145:955-63.

2. Migliore M, Calvo D, Criscione A, et al. Pleurectomy/ decortication and hyperthermic intrapleural chemotherapy for malignant pleural mesothelioma: initial experience. Future Oncol 2015;11:19-22.

3. Iyoda A, Yusa T, Hiroshima K, et al. Surgical resection combined with intrathoracic hyperthermic perfusion for thymic carcinoma with an intrathoracic disseminated lesion: a case report. Anticancer Res 1999;19:699-702.

4. Ambrogi MC, Bertoglio P, Aprile V, et al. Diaphragm and lung-preserving surgery with hyperthermic chemotherapy for malignant pleural mesothelioma: A 10-year experience. J Thorac Cardiovasc Surg 2018;155:1857-66.e2.

5. Burt BM, Richards WG, Lee HS, et al. A Phase I Trial of Surgical Resection and Intraoperative Hyperthermic Cisplatin and Gemcitabine for Pleural Mesothelioma. J Thorac Oncol 2018;13:1400-9.

6. Markowiak T, Kerner N, Neu R, et al. Adequate nephroprotection reduces renal complications after hyperthermic intrathoracic chemotherapy. J Surg Oncol 2019;120:1220-6.

7. Migliore M, Ried M, Molins L, et al. Hyperthermic intrathoracic chemotherapy (HITHOC) should be included in the guidelines for malignant pleural mesothelioma. Ann Transl Med 2021;11:960.

8. Scherpereel A, Opitz I, Berghmans T, et al. ERS/ ESTS/EACTS/ESTRO guidelines for the management of malignant pleural mesotelioma. Eur Respir J 2020;55:1900953.

9. Burns PB, Rohrich RJ, Chung KC. The levels of evidence and their role in evidence-based medicine. Plast Reconstr Surg 2011;128:305-10.

10. Yablonskii P, Nefedov A, Arseniev A, et al. Non-small cell lung cancer, pleural effusion and carcinomatosis: always a criterion of inoperability? AME Med J 2020;5:10.

11. Migliore M, Nardini M. Does cytoreduction surgery and hyperthermic intrathoracic chemotherapy prolong survival in patients with N0-N1 non-small cell lung cancer and malignant pleural effusion? Eur Respir Rev 2019;28:190018.

12. Zhou H, Wu W, Tang X, et al. Effect of hyperthermic intrathoracic chemotherapy (HITHOC) on the malignant pleural effusion: A systematic review and meta-analysis. Medicine (Baltimore) 2017;96:e5532.

13. Migliore M, Halezeroglu S, Mueller MR. Making precision surgical strategies a reality: are we ready for a paradigm shift in thoracic surgical oncology? Future Oncol 2020;16:1-5. 


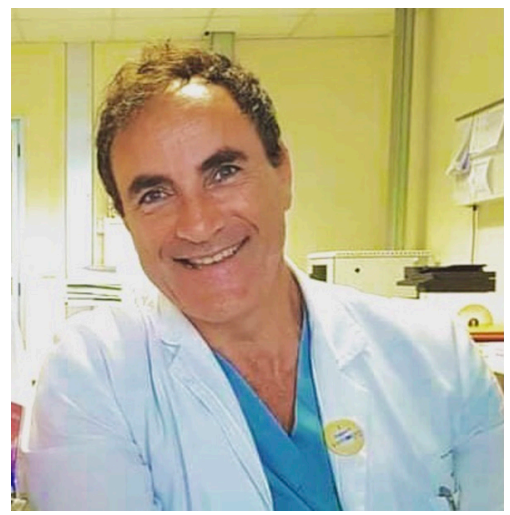

Marcello Migliore

Marcello Migliore ${ }^{1,2}$

${ }^{1}$ Thoracic Surgery, Department of Cardiothoracic Surgery, University Hospital of Wales, Cardiff, UK;

${ }^{2}$ Department of General Surgery and Medical Specialties, University of Catania, Catania, Italy.

(Email: mmiglior@hotmail.com)

Submitted Mar 05, 2021. Accepted for publication Mar 21, 2021. doi: $10.21037 / \mathrm{atm}-21-1040$

View this article at: http://dx.doi.org/10.21037/atm-21-1040

Cite this article as: Migliore M. Present and future of hyperthermic intrathoracic chemotherapy (HITHOC) in thoracic surgical oncology. Ann Transl Med 2021;9(11):952. doi: $10.21037 / \mathrm{atm}-21-1040$ 